\title{
The pervasive nature of power in Central Asia
}

\author{
Filippo Costa Buranelli
}

\begin{tabular}{|c|c|}
\hline Date of deposit & 09032020 \\
\hline Document version & Author's accepted manuscript \\
\hline Access rights & $\begin{array}{l}\text { Copyright (c) } 2020 \text { Taylor \& Francis Group, LLC. This work is made } \\
\text { available online in accordance with the publisher's policies. This is } \\
\text { the author created, accepted version manuscript following peer } \\
\text { review and may differ slightly from the final published version. }\end{array}$ \\
\hline $\begin{array}{l}\text { Citation for } \\
\text { published version }\end{array}$ & $\begin{array}{l}\text { Costa Buranelli, F. (2020). The pervasive nature of power in } \\
\text { Central Asia. Problems of Post-Communism, Latest Articles. }\end{array}$ \\
\hline $\begin{array}{l}\text { Link to published } \\
\text { version }\end{array}$ & https://doi.org/10.1080/10758216.2020.1742163 \\
\hline
\end{tabular}

Full metadata for this item is available in St Andrews Research Repository at: https://research-repository.st-andrews.ac.uk/

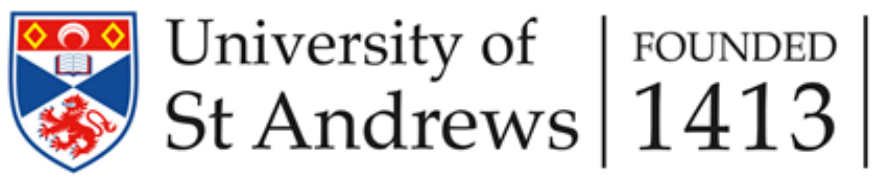




\section{The Pervasive Nature of Power in Central Asia}

\section{Introduction}

The topic of power has recently received renewed international scholarly attention in the field of International Relations (IR), to the point that a recent Annual General Meeting of the International Studies Association in San Francisco, CA, USA was devoted entirely to 'power. 'ii This is an indication that one of the most intractable, yet ubiquitous, concepts within IR and social sciences in general is still far from demising and disappearing. On the contrary, it is making a comeback in daily world politics as well as in the academic field studying it.

This paper intends to contribute to this ongoing discussion in IR by theorizing what I call the 'pervasive nature' of power in Central Asia. The main argument is that power is pervasive, in the sense that it is virtually, and necessarily, present in every analysis of Central Asian politics, be it international, regional, or domestic. More specifically, I believe that what is needed is a comprehensive, holistic framework of analysis that can accommodate different understandings of power and, therefore, its different modes of operation. The necessary premise that I have to make is that, as will be evident in the reminder of the paper, the main concern here is not that of measurement or calculation of power, but rather the understanding its nature and the different relationships informing it.

If this is the task of the paper, then there must be an agreement on what is meant by 'theorizing'. The very word 'theory' comes from the Greek 'theorao', which derives from the root 'thea', that is, 'to see'. Theorization, I believe, begins with description. To describe something means to understand it and to make it understandable. Then, what is described is problematized, unpacked, studied. To theorize means to problematize, and not just the object of our inquiry, but also and perhaps most importantly (for they support our analysis) the ontological, epistemological and 
normative categories that we adopt to problematize something. Therefore, this paper engages not just with 'power' and 'Central Asia', but also with the very act of theorization, with theorizing about theory. For the purpose of this paper, Central Asia is defined as comprising the five post-Soviet republics of Kazakhstan, Kyrgyzstan, Tajikistan, Turkmenistan, and Uzbekistan, in line with the most common definition of the region to be found in the IR literature on the region.

The crucial question that one may still ask with respect to this whole enterprise is: why Central Asia? Why is a call for a more reflexive approach to power analysis in Central Asia being made, and what would the utility thereof be (on reflexivity, see e.g. Campbell 1998)? The answer to this question is twofold. On the one hand, one may argue that more awareness in carrying out power analysis in Central Asia is necessary to then understand, inductively and interpretively, whether or not Central Asia presents forms of power and/or understandings of power that are indigenous, autochthonous, somehow defying Western understandings of the concept. On the other hand, one may argue that an aware analysis of power in Central Asia can potentially de-provincialize and liberate the region from common conceptual straitjackets allowing for multiple forms of power to be dug out and brought to the surface.

A very popular conceptual straitjacket in the field of IR with respect to power and Central Asia, for example, is that of the (new) Great Game. The term, popularized by Rudyard Kipling's 1901 novel Kim, is a widely adopted and popular metaphor, rooted in geopolitical thinking which directly refers to the 19th-century competition between the Russian and British empires for control over Central Asia. It serves the purpose to argue that Central Asia is, in today's politics, a passive object in the broader competition between the US, Russia, China and other states vying for influence in the region (for a recent use of the metaphor, see Blank 2012 and Kamrava 2017; for a critique, see Morrison 2012; Cooley 2012; Sharapova and Megoran 2015; Costa Buranelli 2017; Costa Buranelli 2018). Another popular conceptual straitjacket is that of what can be called the 'authoritarian mantra' of Central Asian studies, that is to say that when discussing 'power' in the region this usually refers to 
coercive and predatory behaviour of the ruling élites (Collins 2009; Lewis 2008; for a critique, see Heathershaw and Megoran 2012, and also Teles-Fazendeiro in this issue).

The paper is structured as follows. In the next section, I offer a discussion of some of the most recent contributions in terms of studies of Central Asian politics framed in terms of 'power'. The purpose of this section is to show how literature dealing with power in the region is indeed thriving and very much making use of 'power' as a concept - yet, this section will also highlight some examples of the persistent presence of the two conceptual straitjackets identified above as well as the lack of conceptual reflexivity, defined as the researcher' awareness of her own theoretical, normative, and political positionality, on the role, the nature, and the character of the object of analysis (in this case, power). The subsequent section discusses the notion of power in the discipline of IR and provides readers with a conceptual history of the term as well as a short overview of the main conceptualizations of it. The third section introduces Michael Barnett's and Raymond Duvall's framework for the analysis of power (2005) to the study of Central Asian politics and makes the case for Central Asian studies to be outspoken in their analysis of power, working within the remit of one of the four categories identified by Barnett and Duvall: coercive, institutional, structural, and performative. The section also re-reads some of the works discussed in the literature review as well as some of the essays featured in this special issue in the light of the framework's analytical precision and shows how a power analysis can be achieved thus bridging Central Asian studies and IR more closely. The last section discusses the implications of the analysis provided in the previous section and discusses some potential trajectories for further research. In the conclusions, the merits and the pitfalls of the present paper will be discussed.

Three caveats are order. First, the fact that the present author comes from a very specific disciplinary domain, that of IR, should be kept in mind by the reader. The points I will make will be pertinent to Central Asia and IR, perhaps neglecting other applications of the theorization of power in other domains. Yet, I still believe that a discussion of the presence of power in Central Asian politics 
from an IR perspective will still be valuable to add an extra layer of complexity to the wider debate on power, which by no means, in my opinion, will approach an end soon, if ever. In fact, one may argue that having a discussion of how power can be theorized in Central Asia from an IR perspective acknowledging merits and limitations is the first, welcome step to value the benefit of a multidisciplinary approach, which is indeed the ultimate goal of this special issue.

Second, and perhaps differently from what one may expect, the paper is not based on a specific empirical case-study, nor does it feature a discussion or analysis of research material or empirics gathered through data-collection. Rather, it seeks to offer a reflexive discussion about how power has (not) been conceptualised in the field of Central Asian studies and what available frameworks of analysis can be adopted to shed more light on this complex social phenomenon.

A third caveat to make is about the meaning of the adjective 'pervasive' as used in the title of this paper and, indeed, in the remainder thereof. The paper does not make the case that power is pervasive only in Central Asia. Simply, 'pervasive' in this paper means that a conceptualization of power in Central Asia should go beyond rigid assumptions about authoritarianism and coercive power as exercised by governments over societies, and rather embrace the fact that 'power' belongs to social life almost constituently, and thus that it can be found operating in complex social webs and dynamics involving governments, societies, institutions, norms, rules, system of thoughts and so on.

\section{A survey of 'power' in Central Asia}

Any discussion of power in Central Asia must begin with an analysis of how power has been conceptualized, defined, treated and analyzed in the field of Central Asian studies. While certainly incomplete for reasons of space, the following literature review may prove to be useful to have an initial glimpse of how power has been treated and conceptualized in recent scholarship. This survey of the literature was performed by indexing 'Power' and 'Central Asia' in Scopus, iv one of the most 
detailed and reliable engines for scholarly works. The two queries were looked for in the titles, as well as in the abstracts and keywords.

I anticipate that this quick survey of the recent literature on Central Asia reveals the following: 1) that there is still very much an understanding of power in structural, materialist terms as 'political regime', 'the state', or, more narrowly, as direct, coercive rule on the side of autocrats - in other words, the two straitjackets identified above are still present; 2) that there is no widespread theoretical reflection on what power is; and 3) that many scholars, while not engaging in power analysis per se in their work, do talk about power. Power, in other words, is often considered a given, but is a widespread and underspecified given. Something happens 'because of power', 'for power', or 'to get power', but what constitutes power is often missing in the analysis (for 'power' as the 'killer argument' in IR, see Guzzini 2013, p.3). In the light of this, the titles discussed in the literature review below are divided into three macro-categories - 'power as political regime/state'; 'power as autocracy'; 'power underdefined'.

It must be clear, to avoid being misunderstood, that what is argued here is not that there is no treatment of power whatsoever in the literature, nor that there is lack of excellent scholarship on the topic of 'power' in the region. More often than not, what is missing is reflexivity about what power is, what its sources are, what its facets are. In other words, the section 'What is "power"' and 'what power' am I looking for?' is often absent in several of the excellent productions on power and Central Asia. 'Conceptual explicitism' is toned down while, I believe, especially when it comes to such an intractable concept such as power, we as scholars should be much more vocal about what we mean by it and how we intend to study it.

Power as political regime/state 
In her impressive 'Institutional Change and Political Continuity in Post-Soviet Central Asia: Power, Perceptions, and Pacts' (2002) Josephine Paul Luong engages in an analysis of institutional change in Central Asia after the demise of the Soviet Union, and of how such change impacts on 'political power,' hinting at a conflation of 'power' and 'authority'. Yet, she does not define it precisely, linking it to 'privilege' (p.13) and hinting at a realist conceptualization of it when she refers to political and economic resources earlier in the text (p. 12).

Another very prominent work for the field, 'Symbolism and Power in Central Asia: The Politics of the Spectacular' edited by Sally Cummings (2009) also does not feature a discussion of power in Central Asia, but it is rather the reader that has the task to unpack it. By relying on materiality and symbolism that Central Asian élites use to entrench authoritarian rule and the processes leading to such entrenchment, it seems that the contributors refer to the nature of political rule as their main referent object. Crucially, in one of her prior articles leading to her contribution to this volume, Anna Matveeva (2009, p.1098) expressed this link when saying that 'symbolism functions as a power display: "in exercising its capacity to appropriate meanings and to insist on the momentary stability of signs, the regime advertises its power. By representing this power, the regime creates it anew, continually upholding the circumstances that produce citizens' compliance (Wedeen 1999, p.157)'.

'Power and Change in Central Asia' by, again, Sally Cummings (2002) is one of the most precise, specific and detailed analysis of how power works in Central Asia, and this is very well expressed in the opening of the book: 'the aim of this book is to reach a sense of where power is in the Central Asian state', to then remind herself and the reader that 'power is a crucial category for political theory, yet it is a very elusive one' (p.3). Later, it is asked 'what does it mean to exercise power in the specific context of Central Asia?' And it is clarified that the purpose of the book is to study authoritarian rule. This is made evident in the following to statements, both on page 2: 'This book is written [with a] basic assumption: leadership matters', and '[the book looks] at the exercise of presidential power in terms 
of leadership roles, institutions, environment and effectiveness'. Yet, what sort of power this 'presidential power' is does not come under theoretical scrutiny, and it is not fully analysed in depth.

Furthermore, in her admirable work on territory, history and politics, 'Movement, Power and Place in Central Asia and Beyond', Madeleine Reeves argues that the central methodological insight is that of Donald Moore, arguing that 'instead of viewing geographically specific sites as the stage already fully-formed constructions that serve as settings for action - for the performance of identities that are malleable (if also constrained and shaped by multiple fields of power), this vision [adopted in the book] insists on joining the cultural politics of place to those of identity'. She is acutely aware of the fact that 'scholars of Central Asia have made significant critiques of the way particular spatial metaphors enter analysis of the region and the political projects they sustain' (p.4) and anticipates that the first part of the volume 'examines the workings of power in the making and transforming of place' (p.8). Yet, a conceptualization of power and its working is in fact missing, thus assuming that power is the same as 'political authority', or 'coercion'. Again, one may assume that the book is very much indeed about 'power', but a theoretical and conceptual definition of what 'power' means in the context that Reeves investigates is not fully developed and, hence, accessible.

The same problem of conflating a 'process' with an 'entity,' assuming for example that 'power' is synonym for 'the state,' is visible in Sharshenova's and Crawford's work on China's attempts to counter EU's democratic norms promotion in Central Asia (2017). In their much welcome contribution, the two authors use 'power' as a substitute for 'the state', resorting to expressions like 'regional powers,' 'nuclear powers,' and 'authoritarian powers'. They also speak of 'democratic empowerment' and 'power of [China's] own example,' rightly highlighting the processual nature of power and its mechanisms in Central Asian societies. Yet, it is unfortunate that both concepts are left a little bit under-theorized and not fully discussed within the wider 'power' framework and literature, thus somehow falling in the (new)-Great-Game trap. 
In one of the most recent and most welcome contributions to the field of Central Asian studies and international relations/international economy, namely 'Dictators without borders: Power and Money in Central Asia' (2017), Alexander Cooley and John Heathershaw discuss how Central Asian elites are linked to the dodgy, opaque financial supra-structure of globalization made up of fiscal heavens and offshore accounts in order to skilfully get profits and personal gains for personal enrichment and regime resilience. Despite the book being sub-titled 'Power and Money in Central Asia', one may find difficult to unpack what power is being talked about in it. The authors seem to equate it, once again, with 'political rule', with 'regime', with 'the autocrats'. This is evident, for example, in the preface and in chapter 7 ('autocrats and their cronies use Western financial, legal policing and political systems to [...] extend their power back home', p. x; 'products of sovereignty which have enabled this extension of dictatorial power', p.xii; 'extraterritorial internal security pertains to the protection of regimes of power from their political opponents in exile', p.191, emphasis in the original). But this, again, may be the result of an analytical and conceptual conflation that does not make the field of Central Asian studies fully sharp and crisp in terms of terminology and analytical clarity when it comes to 'power' and the conceptualization thereof.

'Great powers, civil society and authoritarian diffusion in Central Asia' by Charles E. Ziegler (2016) is another very good example of how foreign actors impact domestic political processes within the Central Asian republics, but again 'power' is a substitute for 'political power,' 'regime,' and not conceptualized in detail. In fact, the analytical shortcomings of the 'authoritarian mantra' ('power as authoritarian coercion') and the (new) great game framework ('autocratic neighbouring great powers push authoritarian norms') are conflated, thus obscuring what 'power' really is in the region and how it is theorized. 
Power can also be the central theme of specific academic works, but as noted in the introduction, this may nonetheless suffer from conceptual underspecification. For example, the book edited by Robert L. Canfield and Gabriele Rasuly-Paleczek, titled 'Ethnicity, Authority and Power in Central Asia' (2010), as is evident, contains 'Power' in the title, but the book does not feature a conceptual discussion of power. Nor 'power' is even featured in the index at the end of the book. The introduction (pp.1-3), in fact, begins with a discussion on the Great Game and the strategic location of the region in international politics, even if the analogy with the Great Game is disputed by the authors.

Moreover, in his account of IMF policies in Central Asia and wider IMF-Central Asia relations (2010), André Broome refers to 'material power' as economic tools for leverage (p.2), but how this power works and is to be understood is not treated in the book. While the chapter 'The Scope of the IMF's Influence in Central Asia' is indeed an account of how the IMF can shape and constrain actors, this is not framed in terms of power theory, or relying on a conceptualization of the specific structural power deriving from international financial institutions, although it is indeed about power.

The argument offered by Heathershaw and Schatz in their 'Paradoxes of Power - The Logic of State Weakness in Eurasia' is also about structures and institutions, as they engage with the dichotomy 'strong/weak' state. They take on the challenge to this dichotomy by convincingly showing how the 'strong/weak' dichotomy obscures elements of complexity in the life, resilience, and performance of states, thus agreeing that states are better described as 'polymorphous', especially in Eurasia despite more than twenty-five years of independence from previous Soviet and socialist experiences have passed (p.3). The fact is that, while it is very clear that there is a 'paradox' in play in Eurasian statehood, that is to say, apparently 'weak states' have proved to be resilient despite high level of internal conflict, informal politics, and non-Weberian state practices, the 'power' element of the edited volume is less apparent. This may be called, with a friendly pun, 'the paradox of paradoxes of power.' It seems that 'power' is understood as the ability of states to be (or rather, to present themselves) as 'strong' despite 'weak' internal governance. Yet, this is not fully explicated in the book, thus letting the reader 
assume that 'power' is used as a synonym for 'state resilience' or a more indefinite 'political power.' In other words, while power seems to be indeed a crucial part of the authors' welcomed argument against the 'strong/weak' analytical distinction that one may frequently find in the IR and political science literature, it is not fully clear how this 'power' is to be theorized and conceptualized.

Finally, framed in a New Great Game narrative, but with the merit of assigning agency to a Central Asian country, the article 'Uzbekistan between the great powers: a balancing act or a multivectoral approach?' by Aleksandr Pikalov (2014) discusses 'power' in the foreign policy of Uzbekistan. Yet, despite 'power' being featured more than fifty times in the article, this concept is not unpacked nor fully theorized.

What seems to be an exception in the vast body of IR and Political Science literature that deals with both 'power' and 'Central Asia' is the work of Filippo Menga, namely 'Power and Water in Central Asia' (2018). In this book, Menga offers a whole chapter (namely chapter 2) on the theorization of power, how power can assume different facets and speak to different segments of social and political life, and how power is linked to hegemony (p.34). Differently from much of the literature reviewed above, in Menga's work not only is the literature on power discussed, but the concept itself is defined clearly. As a matter of fact, combining material and ideational aspects of power (on which more below), Menga defines power as 'the ability, or capacity, of one actor to get the desired outcome through coercive, bargaining and ideational/discursive means' (p.30). The analytical framework that he develops, called 'hydro-hegemony circle', is subsequently linked to the vast literature of power in IR and used to illustrate how 'water' has become an essential tool (one may say 'weapon' in managing regional political relations in Central Asia.

One may now discuss the present status of power in the Central Asian studies literature. To begin with, it is evident from the above that one of the most prevalent ethos in the literature is to use 'power' as a shortcut for 'control', 'domination', 'coercion', 'authoritarianism', and 'political 
authority'. These expressions do have something to do with power. Yet, they are manifestations of it, not the content thereof. They are exemplifications, conceptual substitutes, but not theoreticallyinformed categories. Another factor to take into consideration is that while the works reviewed above place their analysis within a power framework (in other words, ground their analysis within the wider concept of power, and make it part of the overall explanation/argument), there is seldom an explicit discussion of what 'power' is, what aspects of it are of interest, how it manifests itself, through with mechanisms, and what the ontological and epistemological premises behind the adoption of such concept are.

In sum, with perhaps the exception of Menga's work, the purpose of the discussion above, of the short literature review provided, is not to point at the deficiencies, the shortcomings of the works reviewed, but rather to show how it is very difficult to have sharp, crisp analytical studies of what power is and of the many configurations under which power works in Central Asia. It also reveals that the issue of power has indeed occupied minds of political scientists working on the region ever since the independence.

At the risk of generalising and overlooking important exceptions, there seem to be a number of excellent empirical and partly conceptual works on this issue that span from the evolutionary analysis, with some historical perspectives, as well as the usual transitology, 'authoritarianism' claims and 'clan'-clientology discussions. As most of us would agree, majority of these works focus on either the description of the processes that happen with power or on agents who share and fight for that power. Very little discussion, however, has been taking place on what is 'power' itself in these contexts. The ontology of power and its processes of operation within the social world often remain undisclosed.

\section{The concept of power}


It is now time to discuss the meaning and the essence of power. The prominent realist scholar John Mearsheimer has defined 'power' as the currency of great-power politics within the market of IR (2001, p.17; see also Baldwin 1989). This is of course a metaphor to indicate that, in the bazaar of the discipline (to use another metaphor, this time borrowed from Central Asia itself), despite the abundance of goods and the different modalities to deal with negotiations on different disciplinary topics and issues, 'power' is the common denominator of all this - everyone uses it.

Yet, there are problems with this metaphor, the most important of which being the fact that, to continue with the metaphorical narrative, power is a currency with different exchange rates within the discipline. In other words, what counts as power for somebody may mean something else for somebody else, or some forms of power are deemed to be more important than others. This raises a very important conceptual and epistemological point. If power is 'polysemic' and indeed subject to a plurality of views, does this mean that when dealing with power 'anything goes'? I argue that this is not necessarily the case.

If, following Foucault, 'power is everywhere; not because it embraces everything, but because it comes from everywhere [...] Power is not an institution, and not a structure; neither it is a certain strength we are endowed with; it is the name that one attributes to a complex strategical situation in a particular society' $(1998, p .93)$, then it follows that by necessity our focus and analysis will inevitably be on specific aspects, or dynamics, or tensions, within a power-governed society (be the 'society' as small as a family and as big as the international community). The important thing to keep in mind is that analysts should, to the best of their abilities, justify the topic, the focus, and the approach that is taken towards power against other ones available.

As a matter of fact, the way we think about power will define how we deal with power when producing research and knowledge, emphasising what is important, what should be investigated, and with what methods. In other words, reflexivity and definitions of power are linked. This also results in potential conceptual conflation - arguing that 'power' and 'states' or 'ruling élites' are synonyms may 
well obscure and hide important relational dynamics between subjects that are not immediately visible but are in fact present in ideas, behaviours, and narratives. This is also why more reflexivity and self-awareness are needed when analysing and theorizing power in Central Asia. But more on this will be said below.

Within the field of IR, for most of the time and still to a large extent nowadays, realists and neorealists have considered 'power' to be a resource, a property, a possession of a given state or, more in general, actor. This is evident in expressions like 'power resources', 'elements of national power', or 'capabilities', which usually amount to population, territory, wealth, armies and navies (Waltz 1979; Mearsheimer 2001). In his seminal 'On the Concepts of Politics and Power,' Karl W. Deutsch defines power, 'simply and crudely', as 'the ability to prevail in conflict and to overcome obstacles' (1967, p.236), to then measure it using 'Combat-Munitions Output' as its indicator. ${ }^{\vee}$ Yet, this approach was challenged already during the last half of the twentieth century by the 'relational power' approach, developed by scholars working in several disciplines, including psychology, philosophy, sociology, economics and political science and still is challenged by constructivists and methodological interpretivists alike. Baldwin has called this shift from property power to relational power 'the power revolution' (2012).

At this point, one may ask - What is power? How to conceptualize it, how to analytically discern its different components? Where to look for it? As will be evident in the reminder of the paper, the main concern here is not that of measurement or calculation of power, but rather is the understanding its nature and the different relationships informing it.

To begin with, and to almost state the obvious, power is a concept. And what is a concept? Concepts are 'devices we use to order and make sense of a messy reality by reducing its complexity and naming and giving meaning to its features; they provide mental shortcuts through which we navigate and grasp the world by allowing us to cluster, classify and categorize everything we encounter into something manageable and meaningful' (Berenskoetter 2016, p.1). Following Robert Cox (1981), 
and paraphrasing him, one may well argue that 'power is always for somebody and for some purpose'. In other words, what this means is that the way we decide to conceptualize power will drive our analysis theoretically, ontologically, epistemologically and normatively. And, in turn, our theoretical, ontological, epistemological and normative positions will drive our power analysis.

To put it simply, to analyse power in Central Asia means to make Central Asia political. ${ }^{\text {vi }}$ The aim of every power analysis is 'to represent [power] in a way that is suited for description and explanation. But our conception of it may result from and be shaped by what we are trying to explain [...] how we think of power may serve to reproduce and reinforce power structures and relations, or alternatively it may challenge and subvert them [...]. To the extent that this is so, conceptual and methodological questions are inescapably political' (Lukes 2005, p.63 quoted in Berenskoetter 2016, p.17). This is because 'analysing the concept of power is more than defining it' (Guzzini 2016, p.24). It means to unveil specific relations that inform a given social realm, relations that may be based on asymmetries, inequality, hierarchy, control, influence, and to understand the outcomes of them. Therefore, an analysis of power is never innocent, and it is always political. It implies making a choice about what is important, what counts as power, what is worth analysing and to whom explaining it.

However, one should always remember that 'concepts are about ontology. To develop a concept is more than providing a definition: it is deciding what is important about an entity' (Goertz quoted in Guzzini 2016, p.24, emphasis in the original). In other words, the kind of power relations that we decide to study as analysts, scholars and theorists tell a lot about our preferences, both normative and political, about Central Asia and more widely international relations. Power analysis, in sum, is not innocent, and this must be kept in mind at any time. As Berenskoetter notes, 'the meaning we choose determines which relations we consider relevant and where we locate political spaces' (Berenskoetter 2007, p.1, emphasis added). In order to show how power can be pervasive, though, we first need to provide a brief history of the concept and to dissect its various meanings. 
To sum up - like many terms in social sciences, power is an essentially contested and polysemic concept. In other words, it has a context-dependent meaning that is attributed by the scientist/researcher depending on her own normative, epistemological and theoretical assumptions. At the very bottom of every definition and conceptualization of power, at least within the realm of social sciences, there are the two ideas of 'plurality' and 'affect'. With respect to the former, it can be said that 'power' exist only between two or more people or, rather, social actors. If I am alone in the world, there is no one to recognise me, or even just to define me as 'powerful', whatever power entails. This refers to what Dahl has called the 'relational character' of power (Dahl 1957, 202-3).

With respect to the latter, it can be said that 'power' always involves a component of 'alteration' of, 'reaction' to, 'resistance' to, 'control' of, 'affection' on the behaviour or status on the other person(s). In the words of Michael Barnett and Raymond Duvall, 'power is the production, in and through social relations, of effects on actors that shape their capacity to control their fate' $(2005$, 45). The main issue is that a vast part of the IR literature, as argued above, has been attentive to these two aspects of power, but has seldom explored the possibility that they could be combined in a single, holistic and more explanatory framework of analysis. As a matter of fact, while scholars such as Dahl (1957) or Barach and Baratz (1962) focus on coercion or resistance, Lukes $(2005$, p.11) theorizes power as not necessarily coercive and intentional, but rather as shaping '[people's] perceptions, cognitions and preferences in such a way that they accept their role in the existing order of things' (for a wider discussion, see Gwynn 2019 and Teles-Fazendeiro on 'togetherness' in this special issue).

Yet, having multiple and competing conceptualizations of power is not of great help when the goal is to analyse the social world, where arguably different forms of power operate. What is needed, therefore, is a framework that goes beyond different conceptualizations of power by seeing them 'as complementary rather than as alternatives' (Gwynn 2019, p.202). The next section moves on to introducing and reviewing such framework, and its possible application to Central Asia. 


\section{The four dimensions of power and how they operate in Central Asia}

In the light of the previous discussion, the argument of this subsection is that several conceptualizations of power need not be competitive, but can indeed be studied simultaneously, and that this would benefit the field of Central Asian Studies in terms of disciplinary cross-pollination, analytical precision, theoretical clarity, and conceptual synergies. As maintained in the introduction, I argue that what is needed to study power in Central Asia is a comprehensive, holistic framework of analysis that can accommodated its different understandings and manifestations, while at the same time enriching the discipline and making it multifaceted. vii

To achieve this goal, I suggest incorporating within the social scientific strand of Central Asian studies the typology of power as conceptualized by Michael Barnett and Robert Duvall (2005) to show that Central Asia can be seen as an area where the presence and operation of power is pervasive i.e., where power can be seen as operating at multiple levels, between different actors, through different logics, at simultaneous or various times. One may argue, and with good reasons, that it is an application of a Western theoretical typology. It may well be the case that subsequent scholarship will prove the ill-fitted character of it. However, one may also argue that this typology may well constitute a valid starting point to guide theoretically-informed power analysis within Central Asian politics. To be sure, the introduction of this typology does not mean that this typology should be necessarily used by scholars interested in power and Central Asia. Once again, it is important to note that what is being argued in this paper should be interpreted as an invitation to open up spaces for theorization and inquiry, rather than imposing or recommending a specific modus operandi. Likewise, it is important to stress that to privilege Barnett's and Duvall's approach to power, as opposed to the abovementioned conceptualizations, is simply to make a choice in terms of comprehensiveness of framework, rather than explanatory value. In other words, the argument I am making to defend this choice is that Barnett 
and Duvall provide us with a sharper analytical tool (a typology) to deal with an extremely complex concept (power), not that they provide us with a better concept or a better definition of it.

As discussed above, two features of power, however understood, are its relational, social aspect (in the words of Barnett and Duvall 'power [...] is irreducibly social', p.46) and the influence, change embedded in such relation. These two aspects can be fixed into two distinct analytical dimensions: kinds and specificity. The former refers to the polar positions of social relations of interaction and social relations of constitutions' $(2005$, p.42). The latter refers to 'the degree to which the social relations through which power works are direct and socially specific or indirect and socially diffuse' $(2005$, p.43). With respect to kinds, power can be seen either as a resource, a tool, an instrument that is used by one/some to affect the condition(s) of others ('power over') or as an act of constitution, that is, as a formation of identities, roles, (social) positions.

Interactional

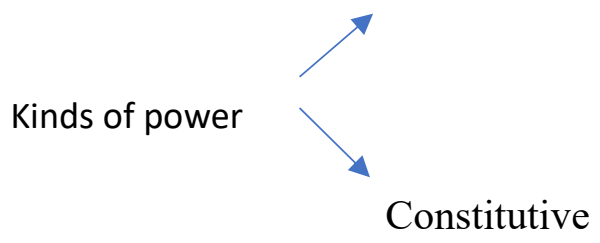

The second dimension of power, specificity, refers to the dichotomy direct/diffuse. This dichotomy has to do with what can be called 'the spatiality of power relations'. Direct power refers to a mechanistic interpretation of power, which then becomes a function of space. The larger the distance between two social actors (be they individual, groups or states), the less the power in play. As defined by Barnett and Duvall, this direct, specific form of power entails 'some immediate and generally tangible causal or constitutive connection between the subject and the object, or between two subjects' $(2005,47)$. Diffuse power, conversely, is not located in a specific spatial or structural domain, but is capillary, pervasive, ${ }^{\text {viii }}$ operating in discourses, narratives, practices, traditions, rituals, rules, norms and institutions that privilege some actors 
over others. It is a form of power that operates daily but is a result of years, if not decades, if not even centuries, of institutionalization and routinization.

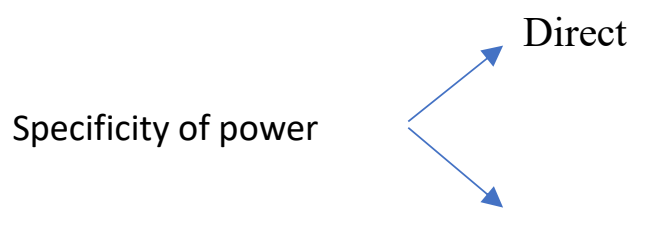

Diffuse

These four aspects of power, if combined, result in the taxonomy below:

[TABLE 1]

Therefore, power can be unpacked into four different dimensions (Barnett and Duvall 2005, 43):

- Compulsory power: direct control by one actor over another; this is the form of power that is mostly recognized by those authors embracing the narrative of a new Great Game in the region;

- Institutional power: influence that actors exercise indirectly over others through diffuse relations of interactions; For institutional power, 'the question is which state controls the regime's agenda, its channels of communication and flows of information, and decides about membership, and thereby enables or prevents participation in the decision-making process (Berenskoetter, 2007, p.9). This is an important aspect of power, as institutions are usually a fait accompli. Power can be exercised in the 
formation and maintenance of institutions, through institutions, within and among institutions. Institutions may reflect power relations, constrain them, or provide the basis for their existence;

- Structural power: this form of power pertains to constitution of subject capacities in direct structural relation to one another;

- Productive power: this face of power refers to the socially diffuse production of subjectivity in systems of meaning and signification. ${ }^{\text {ix }}$ In the words of Foucault, 'we must cease once and for all to describe the effects of power in negative terms: it 'excludes', it 'represses', it 'censors', it 'abstracts', it 'masks', it 'conceals'. In fact, power produces; it produces reality; it produces domains of objects and rituals of truth. The individual and the knowledge that may be gained of him belong to this production' (Foucault 1991, 194, emphasis added).

As an addition to Barnett's and Duvall's typology, I include also a brief, purely indicative discussion of methodology, for different forms of power are based on different epistemologies. To these four different forms of power, one may contend that four different sets of methodology are applicable. This, once again, has the objective of making an analysis of Central Asian politics and international relations not just clearer in terms of what power is in a specific context and what power is operating there, but also to make it more methodologically explicit and vocal.

- Compulsory power: positivist methodology based on observable, direct outcomes;

- Institutional power: institutional analysis, socio-institutionalist approaches, historical institutionalism;

- Structural power: historical sociology, discourse analysis; ethnography; historical methods; 
- Productive power: discourse analysis, ethnography, and genealogical methods to disclose how specific narratives, descriptions and forms of governance have become legitimate and socially acceptable.

A major point of clarification should be provided. The different forms of power discussed above, alongside the methodologies adopted for their study, suggest that power is still, in all its four variants, compatible with influence, control, ability to shape, direct, bend, guide, conceal, reveal, and alter behaviours, ideas, and fates in a relational form. Simply, what the typology suggests is that power has different manifestations, different faces (Lukes 1974), and can be exercised via different tools and mechanisms which can be studied and discussed via different methodologies relying on different epistemologies.

The following question is: How to incorporate studies on Central Asian politics within the framework outlined above? After introducing and explaining the framework ideated by Barnett and Duvall, and after adding to it a discussion of possible methodologies and approaches to study the different faces of power that they identify, it is now time to see how such framework can be used for the study of Central Asian politics. For this purpose, I provide a few, purely indicative research questions based on the different power manifestations discussed above, which can shed light on the international relations of Central Asia and make their analysis more explicit with respect to what power is operating in the region and more theoretically informed, while also showing with examples from this special issue and the wider literature on power and Central Asia which works can potentially fit each kind of power identified above, and how:

- Compulsory power: how are great powers affecting regional order in Central Asia? Through what means? How are Central Asian states resisting external pressure, and what power do they have to deal with strong neighbours? How are Central Asian states 
coping with each other and affecting each other's position in the region? This is the understanding of power that, in broad terms, is employed by those scholars working in the New Great Game paradigm. Among the works discussed in the literature review above, Pikalov's and Ziegler's seem to adhere to this conceptualization of power.

- Institutional power: what is the impact on international organizations on Central Asian systems of governance? What issues and why are on the table of international organizations comprising Central Asian republics or operating there? How are state institutions governing societies in Central Asia, and through what means? To have a sense of how institutional power can be defined and studied in the Central Asian context, Erica Marat's recent study on police reforms in Eurasia (and, with specific reference to Central Asia, in Kyrgyzstan and Tajikistan) does very well in defining police as 'a form of governance of the society, a set of institutionalized practices in everyday life and during extraordinary situations' (2018, p.19). Through her study of police reform, Marat also makes an attempt at escaping an understanding of power in mere coercive terms and at showing the concept's wider application, arguing that '[the] Weberian understanding of police and policing, however, conflates the coercive powers of the police with their ability to deliver a public service in accordance with the needs of society. In this book I have taken a society-centric approach to the study of the police, and I define police as both an institution and a regime' (2018, p.198). In this special issue, the essay of scholars such as Tutumlu and Rustemov, who focus on bureaucratic agents, is a very good example of this kind of power. With more specific focus on the scholarly production reviewed earlier in the paper, one may say that the works of Heathershaw and Schatz, Jones Luong, Broome, and Cummings fall in this remit.

- Structural power: how is capitalism affecting societal and economic development in Central Asia? Through what channels? How is the normative structure of international 
society impacting on Central Asia? How are relations of equality with the great powers, if any, built? How are societal structures and relations informing political and economic life in the Central Asian countries? In this last respect, the recent work on kinship and patronage relations by Aksana Ismailbekova (2017) is an excellent example of how structural power in the region (in her book's case Kyrgyzstan) is pervasive in constituting virtually every aspect of society. Importantly, her work studies power from a multi-faceted perspective, taking into account original and ground-breaking anthropological scholarship on Central Asia such as Beyer's (2016) and Reeves et al.'s (2014). This is something that I call 'interdisciplinarity of power,' which will be further elaborated on below. Another very good example of a work employing a structural understanding of power is Regina Spector's book on bazaar economies and trade orders in Central Asia (2017). In it, the author focuses on the role that social and economic structures pre-existing to neo-liberal principles imported in the region are creating islands of order in the Central Asian economies which are partly complementary, partly competing with market structures at the international level. Among the works cited in the literature review above, Menga's production offers another clear example of a structural conceptualization of power, alongside the work of Heathershaw and Cooley on how the structure of capitalism and financial neoliberalism empowers Central Asian élites.

- Productive power: who produces the categories of 'terrorist' in Central Asia, and how? Through what means? What are the processes that lead to the creation of such categories? How has 'stability' become the mantra of the region, alongside order and authority? Through what means? By what metaphors? A recent example of this is Lewis's 'Blogging Zhanaozen: Hegemonic discourse and authoritarian resilience in Kazakhstan' (2016), as well as Omelicheva's 'Authoritarian legitimation: assessing 
discourse of legitimacy in Kazakhstan and Uzbekistan' (2016), in which she shows how 'authoritarian governments can foster certain modes of reasoning and evaluation among citizens, and create possibilities for their acceptance of the regime as "right" or "proper"” (2016, abstract). ${ }^{\mathrm{x}}$ Specifically in this special issue, a very good account of productive power is offered by Totaro, who through ethnographic methods shows how hegemonic narratives and discourses around terrorism in Kazakhstan are so much embedded in society to be almost perceived as 'affections', creating a state of indeterminacy as to whether 'terrorists' or 'the state' itself is the main source of insecurity. Conversely, going back to the scholarship reviewed above, one may argue that the accounts offered by Matveeva and Reeves also rely, in their respective realm of investigation, on a productive conceptualization of power based on narratives and symbols.

Yet, 'although each concept offers important insights into how power operates, a full accounting of power requires a consideration of its multiple forms operating in relation to each other' (Barnett and Duvall 2005, p.57). The hope is, therefore, that power analysts working in and on Central Asia will focus on drawing connections between different manifestations of power, showing feedback effects, mutual enhancement and multiple power strategies at play in the politics of the region to finally show the pervasive nature of power in Central Asia.

\section{Power analysis,Central Asia, and the 'interdisciplinarity' of power}

Having discussed the typology of power and its several manifestations, a question arises almost spontaneously: Why do we need to know that Central Asia is an area of pervasive power? The answer to this question may indeed lie in the wider conceptualization of a still somehow fragmented field of 
study, that of Central Asia or, if you prefer, Eurasia. If it can be shown that a pervasive, unifying, transversal factor that characterizes the region is that of power, then it follows that better synergies can be built across disciplines and traditions, for the purpose of better analysis and study of the region. To show that power is pervasive in Central Asia is an analytical effort as much as a call for more entrenched interdisciplinary dialogue. More on this will be said below.

This paper has made the argument that levels of analysis and a multiplicity of viewpoints are of the utmost importance to start dissecting power relations to have a better, more solid analytical grip of them. And the typology above, implicitly, recognizes this fact. Power can be seen as operating within between individuals, within states, between states, at the level of the (regional) international structure. This is complex, both in methodological and procedural terms, especially in terms of research design. Yet, it very much mirrors the complexity of what is a stake here: the pervasive nature of power.

An analysis of power relations in Central Asia, and the recognition that power is inescapable inevitably leads to renovated and deeper reflexivity on the side of the theorist/researcher. Reflecting on our theoretical, ontological, epistemological and normative positions, we will be able to better define and justify our scope of action and our scholarly activity when it comes to defining what matters in the region. And this, in a virtuous circle, will lead to better positionality, and a better understanding of what we research and why.

Before concluding these reflections, one final point on the Western-centric nature of this (that is, my) enterprise is in order. I have already acknowledged above that in my attempt to enhance reflexivity on the pervasive nature of power in Central Asia through the adoption of Barnett's and Duvall's typology, I may be falling in the trap of Western-centrism (even if the application thereof may well reveal, as said, autochthonous theories of power). As a social concept, 'power' is the product of a specific process of knowledge production, analysis, assumptions and historic-cultural traditions. This is inescapable. Therefore, I argue that Central Asian scholars should feel a crucial part of this debate, 
contributing with their systems of knowledge, experiences, political and normative lexicon to how better conceptualize 'power'. Some of the works discussed above, produced by Central Asian scholars, very much speak to this welcome would-be trajectory. Therefore, for the field of Central Asian studies an analysis of power based on explicit reflexivity cannot be anything but useful to avoid (or at least acknowledge) some sort of intrinsic Western-centrism and Western logocentrism in the application of the concept, thus revealing and exploring potential avenues for theoretical conceptualizations of power that rely on a closer link between the theorist and the social environment under examination.

As Guzzini reminds us, 'no analysis of power can be made without knowing the relative importance of conflicting values and preferences in the mind of the power recipient, if not also of the supposed power holder' $(2013$, p.5). Also, albeit dated, the lesson of Lasswell and Kaplan is still very much relevant when it comes to analyse power in specific geographical and cultural contexts: 'Political analysis must be contextual and take account of the power practices actually manifested in the concrete political situation' $(1950,94)$.

Conceptual analysis, when it comes to power, should work as building bridges between disciplines, investigating spaces for interactions. Yet, it should be remembered that debates about how best to understand power are not politically innocent, as 'it is not enough to show that wider concepts allow more or other phenomena to be seen - one also needs to provide a common metatheory for analysis across the existing power concepts to account for such wider phenomena in a theoretically coherent manner' (Guzzini 2016, 33). And, as anticipated above, meta-theoretical categories are often chosen on specific, politically-driven ontologies, forms of knowledge and conceptions of the 'good' and the 'right'.

In the light of the above, I believe that the most fruitful way to study power in the Central Asian context is, first of all, to remind ourselves that to study power is to engage with the social. If, as argued above, it is true that power is relational and therefore meaningful, intelligible and observable in a given social context, then there is no reason as to why the analysis and application of this concept 
should be private property of IR only. Acknowledging the interdisciplinarity of power, anthropologists, geographers, historians, philosophers and historians of art, for example, can contribute an analysis of power that is less accessible, less visible and more obscure to positivist IR scholars and provide new methodologies and interpretivist tools for analysis (a historian of art, for example, may investigate how specific artworks embody power and contribute to legitimization strategies carried out via an exercise of productive power - see Adams 2010).

We, as theorists, are engaged in knowledge production every day, and such production, which follows our normative and epistemological and ontological preferences and assumptions, gets engrained, diffused and embodied in discourse, knowledge and 'regimes of truth' (Foucault 1991). As well-established scholars have observed (Reeves 2012; Megoran 2007; Megoran and Heathersaw 2011), defining territories and regions and their spatial terms is a political act, and therefore an act of power. A thorough analysis of the pervasive nature of power in Central Asia should therefore address the issue of Eurocentrism, foster an awareness of methodological and epistemological questions, clarity about how to study power (something that Barnett and Duvall do not do), and integrity of inquiry.

This is all the more necessary, as 'to do social science is not to serve a certain political programme, but to model the social and highlight inconsistencies and the costs of doing stuff in this fashion rather than that (Neumann 2012, p.339), thus impacting on, for example, funding, pressure from the outside for money and grants. And for the study of Central Asia, this is of utmost importance. To sum up what just said, one may argue that what Foucault says about the nature of productive power is valid in Central Asian studies as well as in other disciplines, and theorists should be acutely aware of this when engaging with power analysis:

'Truth is a thing of this world: it is produced only by virtue of multiple forms of constraint. And it induces regular effects of power. Each society has its regime of truth, its "general politics" of truth: that is, the types of discourse which it accepts and makes function as true; the mechanisms and instances which enable one to distinguish true and 
false statements, the means by which each is sanctioned; the techniques and procedures accorded value in the acquisition of truth; the status of those who are charged with saying what counts as true' (Foucault quoted in Rabinow 1991, 73).

\section{Conclusions}

By relying on the typology drawn by Barnett and Duvall, this paper has made a case for a multi-faceted theorization of power in Central Asia with particular (though not exclusive) reference to the field of IR. Its core argument is that if Central Asia is considered as a 'political' field, i.e. as an area where specific decisions, values, representations, discourses are contested, negotiated, produced, and implemented, then Central Asia is indeed pervaded by power, in all its different forms. The literature review presented at the beginning of the paper aimed to show not the lack of power as a concept in Central Asian studies, but rather the underdeveloped character of the theorization thereof and of the reflexivity associated to its use. Then, the application of the typology on different strands of works and research on and in Central Asia meant to encourage scholars not to think of power as a monolithic, single concept, but rather as a polysemic, contested concept that can be theorized, studied and analysed through multiple connections and linkages across its different facets. As could be seen, recent scholarship produced by both non-regional and Central Asian scholars is becoming increasingly aware of the complexity of power, and more prone to study the concept in its different manifestations.

To paraphrase Barnett and Duvall, the aim of this paper is to even more 'encourage scholars to see different forms of power in [Central Asia] and the connections between them, [and] to imagine how different forms [of power] interact to sharpen empirical analysis' $(2005,68)$.

A subtler, underlying but nonetheless important aim of this paper and more specifically of the application of the typology on Central Asian studies, has been also that of showing that IR needs other disciplines to explore the pervasive nature of power in the region, its different manifestations and loci of operation. 
The third, last aim of this paper has been that of encouraging scholars working on power in Central Asia to theorize about theory and to reflect on their metatheoretical assumptions for the sake of better conceptual and empirical analysis and for the sake of problematizing some potential Western-centrism that imbues our engagement with 'power' and the region.

To be sure, it is also important to specify what this paper did not try to do. By advancing the adoption of a typology of power, the argument was not that there is a specific Central Asian form of power, nor that there is anything distinctively Central Asian about power. The paper does not, and perhaps cannot, answer the question as to whether there is something specific to power in Central Asia. Or for that matter, whether there is a Central Asian power. This, first of all, would constitute a reductio ad unum of a complex region in which power can find different manifestations in different domains. To argue that in a whole region there is a distinctive mode of power operating would somehow silence different facets of this phenomenon. While there may definitely be indigenous traits in how specific forms of power are produced and enacted in the region, this would nonetheless require a much more in-depth study than the present one, and would have to make the case that power, rather than being a general social fact (which is the thesis in this paper and indeed in this special issue), is a contingent, localized one. In other words, I am not in a position to make such an argument, but at the same time it is not entirely what this paper is interested in - which is, conversely, the problematization of power as an umbrella concept and the display of its different forms of operation in the region.

If, however, the incorporation of more reflexivity about the nature of power and the operation thereof in the region will lead to the discovery of localized, indigenous practices in Central Asia, this will indeed a further proof of the utility of the enterprise and may well lead to the creation of a comparative research agenda on how power is performed and interpreted in different world regions. 


\section{Notes}

\footnotetext{
${ }^{i}$ In this paper, I follow the usual convention to speak of 'International Relations' (IR) to mean the disciplinary field of global politics, while I speak of 'international relations' to refer to political, diplomatic and economic interactions between states and other relevant actors.

ii 'The Power of Rules and Rules of Power', ISA Annual General Meeting, San Francisco, CA, USA, April 2018.

iii I am very much aware that this, as will be evident in the remainder of the paper, is in itself an act of power, which prioritizes, legitimizes, and includes certain narratives and approaches to the region while marginalizing and excluding others.
}

iv https://www.scopus.com/search/form.uri?display=basic. As one reviewer astutely argued, performing the literature search for this paper through Scopus is in itself an act of disciplinary power, as Scopus incorporate only works that comply with its Western parameters and standards. I cannot but acknowledge this fact, and while this proves that more in-depth literature reviews on power and Central Asia are needed, it also proves that power is very much diffused in every-day actions, which is one of the main arguments of the paper itself.

${ }^{v}$ Combat-Munitions Output include aircraft, army ordinance and signal equipment, naval vessels, and related equipment.

${ }^{v i}$ For the intersection between political and power, see Karl Deutsch (1967: On the concepts of politics and power).

vii Yet, as Guzzini cogently remind us, there are limitations in putting together different aspects of power into a single research design.

viii In this context, 'pervasive' refers to a specific dimension of power as identified by Barnett and Duvall, that is, productive power. Yet, the title of the paper uses 'pervasive' differently, referring to the fact that 'power' is a far more present and multifaceted concept in Central Asian studies than it is commonly acknowledged. 'Productive power' is only one dimension of this wider presence of the concept (and, indeed, of power itself!)

${ }^{\text {ix }}$ Of course, all these facets 'power' involve a discourse of 'resistance' as well, but this is not the focus of the paper.

${ }^{x}$ Yet, Omelicheva seems to conflate compulsory power (specific policies deriving from authoritarian rule) and productive power (creation of legitimating narratives informing what is 'true' and 'right'). This is evident when she argues that 'legitimate power' rests on the presidents' discourses and 'certain modes of reasoning and evaluation among citizens'. Yet, such discourses and the production of modes of reasoning and evaluation are clear instances of (productive) power in themselves!

\section{References}

Adams, Laura L. 2010. The Spectacular State: Culture and National Identity in Uzbekistan. Durham: Duke University Press.

Bachrach, Peter and Morton S. Baratz. 1970. Power and Poverty. New York, London: Oxford University Press.

Baldwin, David. 1989. Paradoxes of Power. First edition. New York, NY, USA: Wiley-Blackwell.

Baldwin, David A. 2016. Power and International Relations: A Conceptual Approach. Princeton, New Jersey: Princeton University Press. 
Barnett, Michael, and Raymond Duvall. 2005. "Power in International Politics." International Organization 59 (1): 39-75.

Berenskoetter, Felix. 2016. "Unpacking concepts" in Berenskoetter, Felix. Concepts in World Politics. 1 edition. Los Angeles: SAGE Publications Ltd.

Berenskoetter, Felix, and Michael Williams, eds. 2007. Power in World Politics. 1 edition. London ; New York: Routledge.

Beyer, Judith. 2016. The Force of Custom: Law and the Ordering of Everyday Life in Kyrgyzstan. Pittsburgh: University of Pittsburgh Press.

Blank, Stephen. 2012. "Whither the New Great Game in Central Asia?" Journal of Eurasian Studies 3 (2): 147-60.

Broome, André. 2010. The Currency of Power - The IMF and Monetary Reform in Central Asia. Basingstoke : Palgrave Macmillan.

Campbell, David. 1998. Writing Security: United States Foreign Policy and the Politics of Identity. 2nd edition. Minneapolis: University of Minnesota Press.

Canfield, Robert L., and Gabriele Rasuly-Paleczek. 2010. Ethnicity, Authority and Power in Central Asia: New Games Great and Small. London: Routledge.

Collins, Kathleen. 2009. Clan Politics and Regime Transition in Central Asia. Cambridge: Cambridge University Press.

Cooley, Alexander. 2012. Great Games, Local Rules: The New Great Power Contest in Central Asia. Oxford: Oxford University Press.

Cooley, Alexander., and John Heathershaw. 2017. Dictators without Borders: Power and Money in Central Asia. New Haven: Yale University Press.

Costa Buranelli, Filippo. 2017. "The New Great Game That Is Not." New Eastern Europe, 2017.

- - - 2018. "Spheres of Influence as Negotiated Hegemony - The Case of Central Asia." Geopolitics 23 (2): 378-403.

Cox, Robert W. 1981. "Social Forces, States and World Orders: Beyond International Relations Theory." Millennium 10 (2): 126-55.

Cummings, Sally, ed. 2001. Power and Change in Central Asia. 1 edition. London; New York: Routledge.

Cummings, Sally N. 2009. Politics of the Spectacular: Symbolism and Power in Central Asia. London: Routledge.

Dahl, Robert A. 1957. "The Concept of Power." Behavioral Science 2 (3): 201-15.

Deutsch, Karl W. 1967. "On the Concepts of Politics and Power." Journal of International Affairs 21 (2): 232-41.

Foucault, Michel. 1991. Discipline and Punish: The Birth of the Prison. London: Penguin.

- - . 1998. The History of Sexuality: The Will to Knowledge: The Will to Knowledge v. 1. London: Penguin. 
Guzzini, Stefano. 2013. Power, Realism and Constructivism. Routledge.

---. 2016. "Power" in Berenskoetter, Felix. Concepts in World Politics. Los Angeles: SAGE Publications.

Gwynn, Maria A. 2019. "Structural Power and International Regimes." Journal of Political Power 12 (2), 200-223.

Heathershaw, John, and Nick Megoran. 2011. "Contesting Danger: A New Agenda for Policy and Scholarship on Central Asia." International Affairs (Royal Institute of International Affairs 1944-) 87 (3): 589-612.

Heathershaw, John, and Edward Schatz, eds. 2017. Paradox of Power: The Logics of State Weakness in Eurasia. Pittsburgh: University of Pittsburgh Press.

Ismailbekova, Aksana. 2017. Blood Ties and the Native Son: Poetics of Patronage in Kyrgyzstan. Bloomington: Indiana University Press.

Kamrava, Mehran. 2017. The Great Game in West Asia. London.

Lasswell, Harold D., and Abraham Kaplan. 2013. Power and Society: A Framework for Political Inquiry. Transaction Publishers.

Lewis, David. 2008. The Temptations of Tyranny in Central Asia. Hurst.

---. 2016. "Blogging Zhanaozen: Hegemonic Discourse and Authoritarian Resilience in Kazakhstan." Central Asian Survey 35 (3): 421-38.

Lukes, Steven. 1974. Power: A Radical View. London; New York: Macmillan.

- - . 2005. Power: A Radical View. $2^{\text {nd }}$ Edition. London; New York: Macmillan.

Luong, Pauline Jones. 2002. Institutional Change and Political Continuity in Post-Soviet Central Asia: Power, Perceptions, and Pacts. Cambridge University Press.

Marat, Erica. 2018. The Politics of Police Reform: Society against the State in post-Soviet Countries. New York: Oxford University Press.

Matveeva, Anna. 2009. "Legitimising Central Asian Authoritarianism: Political Manipulation and Symbolic Power." Europe-Asia Studies 61 (7): 1095-1121.

Mearsheimer, John J. 2001. The Tragedy of Great Power Politics. W. W. Norton \& Company.

Megoran, Nick. 2007. “On Researching 'Ethnic Conflict': Epistemology, Politics, and a Central Asian Boundary Dispute." Europe-Asia Studies 59 (2): 253-77.

Menga, Filippo. 2017. Power and Water in Central Asia. 1 edition. New York: Routledge.

Morrison, Alexander. 2008. Russian Rule in Samarkand 1868-1910: A Comparison with British India. New York: Oxford University Press.

Neumann, Iver B. 2014. “International Relations as a Social Science." Millennium 43 (1): 330-50.

Omelicheva, Mariya Y. 2016. "Authoritarian Legitimation: Assessing Discourses of Legitimacy in Kazakhstan and Uzbekistan." Central Asian Survey 35 (4): 481-500. 
Pikalov, Aleksandr. 2014. "Uzbekistan between the Great Powers: A Balancing Act or a Multi-Vectorial Approach?" Central Asian Survey 33 (3): 297-311.

Rabinow, Paul, ed. 1991. The Foucault Reader: An Introduction to Foucault's Thought. New edition. London: Penguin.

Reeves, Madeleine, ed. 2012. Movement, Power and Place in Central Asia and Beyond: Contested Trajectories. London: Routledge.

Reeves, Madeleine, Johan Rasanayagam, and Judit Beyer, eds. 2014. Ethnographies of the State in Central Asia: Performing Politics. Bloomington: Indiana University Press.

Sharapova, Sevara, and Nick Megoran, eds. 2013. Central Asia in International Relations. London: Hurst And Company.

Sharshenova, Aijan, and Gordon Crawford. 2017. "Undermining Western Democracy Promotion in Central Asia: China's Countervailing Influences, Powers and Impact." Central Asian Survey 36 (4): 45372.

Spector, Regina. 2017. Order at the Bazaar: Power and Trade in Central Asia. Ithaca: Cornell University Press.

Waltz, Kenneth N. 1979. Theory of International Politics. New York: Random House.

Wedeen, Lisa. 1999. Ambiguities of Domination: Politics, Rhetoric, and Symbols in Contemporary Syria. 2nd First Edition, Enlarged Edition. Chicago: University of Chicago Press.

Ziegler, Charles E. 2016. "Great Powers, Civil Society and Authoritarian Diffusion in Central Asia." Central Asian Survey 35 (4): 549-69. 